\title{
Business Development of Base Transceiver Station (BTS) Infrastructure Contractor PT. XYZ
}

\author{
Biyal Muhajirin Koswara', Rizal Syarief ${ }^{1}$, Harianto $^{1}$ \\ ${ }^{1}$ IPB University, School of Business, Jl. Raya Pajajaran Bogor, Indonesia \\ Corresponding Author: Biyal Muhajirin Koswara
}

\begin{abstract}
The growth of BTS which is the main infrastructure in the implementation of telecommunications is needed for service and improvement of the quality of telecommunication networks, especially in pandemic times. The goal to be achieved In order to formulate the company's strategic planning to develop its business, information is needed about what business model is currently adopted by the company, what factors affect the company's current position in the market that will give rise to alternatives to the company's strategy, and what are the alternative strategies that are priority strategies and suitable for the current condition of PT. XYZ. The analysis method used is Business Model Canvas (BMC), Strength Weakness Opportunity Threat (SWOT) and Quantitative Strategic Planning Matrix (QSPM) Based on the results of the study, BMC told PT XYZ, that the business model of the company can still sustain its business operations but there are some slight shortcomings that need to be improved to maximize the elements that can increase profits from the company. The results of the analysis of strategy formulation and SWOT analysis resulted in seven alternative strategies. In the QSPM analysis, the main priority strategy is training and development human resources.
\end{abstract}

Keywords: BMC, Business Operations, PT XYZ, QSPM, SWOT

\section{INTRODUCTION}

Transformation in various fields is certainly very useful for the public because with the tighter the competition, then the products or services produced will also be better quality. In Indonesia the use of technology has certainly become the primary thing in everyday life, especially the use of smartphones in every activity so that it is almost owned by everyone. The use of smartphones or smart phones in Indonesia is predicted to continue to increase. In 2015, only $28.6 \%$ of the population in Indonesia used the device. Over time, smart phones are increasingly affordable, thus increasing their use as well. More than half of Indonesia's population, or $56.2 \%$, used smartphones in 2018. A year later, $63.3 \%$ of people used smartphones. As of 2025 , at least $89.2 \%$ of Indonesia's population has taken advantage of smartphones. In the six years since 2019, smartphone penetration in the country grew by $25.9 \%$ (Katadata, 2020).

Evidently in 2017, 54.68 percent of the total population is active internet users, in 2018 there were 64.80 percent even the number of internet users in Indonesia until the second quarter of 2020 reached 196.7 million or 73.7 percent of the population. This number increased by about 25.5 million users compared to last year. (APJII 2019). There is a growing demand at all times as well as primary needs for the country in the development of infrastructure that supports the use of technology, especially smartphones (smartphones).

But at the beginning of 2020 there was a Covid-19 pandemic that changed the dynamics of business and economic order in various fields, all companies both large and 
small felt a fairly detrimental impact with the decline in economic growth itself even many businesses closed and forced to lay off employees so that the increasing problem of unemployment and so on. Seeing the obstacles to the Covid-19 pandemic, almost all businesses and companies like repeating the pandemic and starting from the beginning of the business because all the ways of business work changed slightly before and during the pandemic.

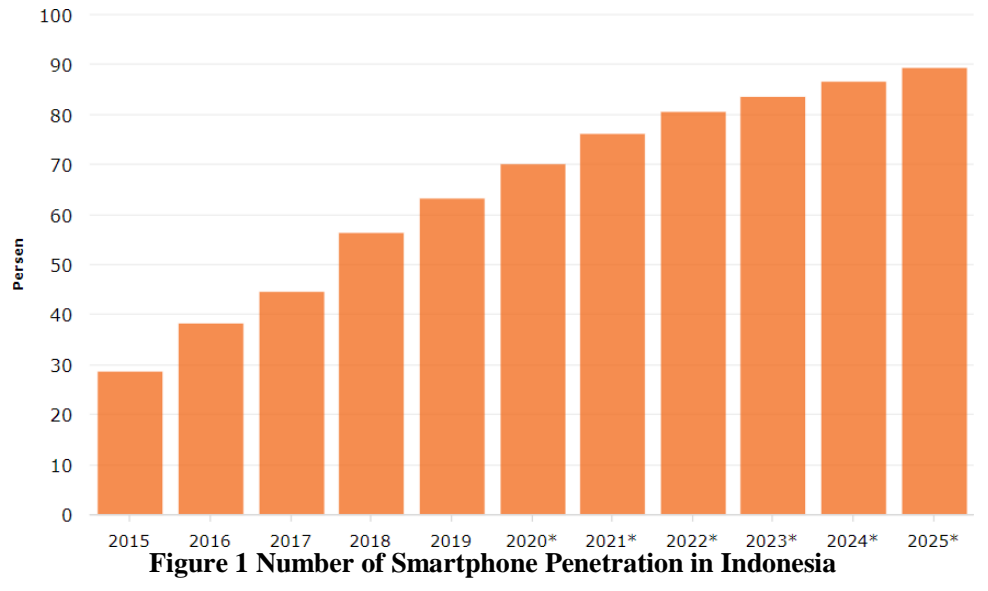

One of the contracting companies implementing the construction of BTS is PT. XYZ located in Duren Sawit, Jakarta. PT. XYZ is working on the construction of BTS Tower with the main customers, namely from 3 large non-operator BTS Tower providers (Tower Provider) with the following details.

Table 1 Details of Total Project PT. XYZ

\begin{tabular}{|l|l|l|l|}
\hline Tower Provider & & Year & \\
\hline & $\mathbf{2 0 1 9}$ & $\mathbf{2 0 2 0}$ & $\mathbf{2 0 2 1}$ \\
\hline PT. Centratama Menara Indonesia & 29 & 61 & 18 \\
\hline PT. Tower Facilities Nusantara & & & 3 \\
\hline $\begin{array}{l}\text { PT. Core Wake } \\
\text { Prosperous }\end{array}$ & 28 & & 63 \\
\hline Total Source: Internal (2021) & 61 & 84 \\
\hline \multicolumn{4}{|c|}{} \\
\hline
\end{tabular}

As for the internal problems that have been faced by PT. XYZ is a sluggish pandemic economy, can be seen from the value of the device installation project as a sub-contractor that decreases and also the company's revenue decreases over time due to this situation. The decrease in revenue is due to delays in payments from customers, namely Tower Provider companies themselves due to their cash flow being hampered by the pandemic, although there is an increase in the number of projects undertaken, but the absence of funds makes operations to build a BTS Tower hampered.
Here is the revenue data of PT. XYZ within the last 5 months.

Table 3 Revenue of PT. XYZ

\begin{tabular}{|l|l|}
\hline Moon & Revenue (billions of rupiah) \\
\hline September 2020 & 120.1 \\
\hline October 2020 & 96.1 \\
\hline November 2020 & 85.5 \\
\hline December 2020 & 60.2 \\
\hline January 2021 & 51.9 \\
\hline
\end{tabular}

The decline in revenue that occurred in the last 5 months makes the company have to think again to continue to survive amid the sluggish economy of development due to this pandemic so that the company can compete, survive, and also to keep meeting the market demand for the growing needs of mobile phone signals.

Business development of PT. XYZ is not only supported by careful strategic planning to increase the company's revenue, but also in order to survive in the midst of uncertainty. In order to formulate the company's strategic planning to develop its business, information is needed about what business model is currently adopted by the company, what factors affect the company's current position in the market that will give rise to alternatives to the company's strategy, and what are the alternative strategies that are priority strategies and 
suitable for the current condition of PT. $\mathrm{XYZ}$

\section{METHODS}

This research was conducted at PT. $\mathrm{XYZ}$ is located in Duren Sawit East Jakarta. With the pressure of market demand for BTS that continues to increase and but with sluggish economic conditions make the company's money turnover slowed than it should. This certainly requires serious attention from the company, therefore it takes the formulation of new priority strategies for business development in order to survive this sluggish period. The time of data collection in this study was conducted from May to July 2021.

The method used in this study is qualitative and descriptive research by taking a type of case study that aims for a study to have more detailed and thorough results on a particular object that is usually relatively small within a certain time (Umar, 2010). Descriptive research can describe an informative picture and also the condition of the object, namely the company factually and systematically. The data that will be used in this study is primary data and secondary data. Primary data is data obtained directly through the interview process or in depth interview with the help of questionnaires and predetermined respondents. This primary data relates to the specific purpose of research, namely answering the formulation of problems and producing several business strategies (Sarwono, 2006). Information obtained from interviews related to the problems faced, activities carried out, the condition of resources owned, and the opportunities and threats faced by the company. Secondary data is data obtained from literature studies and literature from various relevant sources of previous studies. Here is an explanation of the methods carried out in the data collection process. The analysis here uses a qualitative approach that will formulate a business model of the company with BMC, then SWOT and AHP.

\section{RESULTS \\ Business Model Identification}

The stage is done by identifying the nine building blocks of the business model that is running at $\mathrm{PT} X Y Z$ and then describing it on the Business Model Canvas. Companies that want to improve their business continuity must change their business model that can be implemented inkramental (little by little on a regular basis) (Boons and Freund 2013).

According to Ostewalder and Pigneur (2012) customer segments are divided into five parts: open market (mass), niche market (special), segmented market, diversified market and market with multiple platforms. Currently customer segmentation served by the company is an open market (mass) where the company serves customers from all walks of life.

PT XYZ serves the company's customers tower providers and device providers as the services of the main contractor and subcontractor of telecommunication tower construction. The main company that is a customer of both segments at this time is PT. Centratama Indonesia as the main contractor service provider of the construction of menara and PT. Nokia Solutions and Networks Indonesia as a provider of device installation services on a telecommunications company with business to business principles because it already has a cooperation contract between the two parties.

Table 4 Project two Main Customers

\begin{tabular}{|l|l|l|}
\hline No. & Project and Project Value & Year \\
\hline 1 & PT. Centratama Indonesia & \\
\hline & 29 & 2019 \\
\hline & 61 & 2020 \\
\hline & 18 & 2021 \\
\hline 2 & PT. Nokia Solutions and Network Indonesia & \\
\hline & 15 Billion & 2018 \\
\hline & 8 Billion & 2019 \\
\hline
\end{tabular}

A value proposition is a plus or something that is offered by the company to customers to be able to meet and solve customer needs. One way that companies do to build trust is to provide assurance that the company will always be ready to provide 
service to customers through improving the quality of service (Band and William 1991). According to Dimagronas et al the focus of the value proposition of customers should be based on two points of view, namely industry and government. Customer satisfaction is the most important thing that customers need. Currently, the company uses product diversification by continuously increasing product offerings with the concept of "Beyond Space" to consumers. So that the facilities in each apartment are different and can attract consumers to buy.

In this block outlines the value offered by the company to make consumers still choose the company to complete the construction of the Tower. The creation of a new value proposition on the design of future business models will affect every element in the canvas business model. (Azhar et al, 2017).

The company offers "all-area" jobs that include one and done without having to think about other things, so that technical and regulatory work can be fulfilled on the desired schedule.

The company offers specifications that are qualified in accordance with the needs of the current market by using the latest technological tools so as to accelerate the completion of work.

TrackRecord, PT XYZ has a good selling point among the BTS industry because so far the company does a job order always in accordance with the schedule and lead-time that consumers want.

Business to business activities that acquire goods and services used to produce other products or services sold, leased or supplied to others (Kotler and Keller 2016). PT XYZ delivers the company's value offering by combining direct and indirect methods. Direct channels used by the company include through open bidding when tower providers conduct vendor auctions and also competitive contractpaying offers that are directly submitted to consumer companies.

In addition, the company uses networking networks that have been built so far against players in the telecommunications tower industry. For marketing, the company has sought to open a wider network by opening branch offices in potential regions and forming competitive teams across the region in order to at least be known first by local players. But so far promotional activities have not been efficient because of some networking is not maximal and is below the company's target. In addition, the company also uses the services of marketing agents in marketing, the cost incurred is $4 \%$ of the total revenue that has been determined. But some projects have not been able to make the most of the existence of marketing agents.

In this element describes the relationship made by the company to the customer segmentation that has been determined. According to Wijaya and Danuranto (2009) explained that Customer Relationship Management (CRM) is a strategy used to maintain the stability and sustainability of the company's operations. One way to approach customers is through communication skills in improving service to demand. This application can be developed to get a new costumer (acquire), improve the relationship with the costumer (enhance) and maintain the costumer (retain) which results in customer loyalty.

PT XYZ with its consumers who are large companies and certainly have stronger bargaining value. So the relationship built to keep them afloat is to maintain the quality of tower and device specifications as promised at the beginning, complete the work on time according to the schedule that has been set, and maintain coordination quickly and real-time. As long as the track record of work is maintained properly then consumers still choose PT XYZ to complete the work.

The company has revenue streams through tower construction services and installation of BTS devices. Payments made by consumers are by way of Termyn in accordance with the progress that has been done by the company where the payment is made through bank channels that have 
cooperated, then healthy bank traffic is the key to the company in carrying out its business operations during this year.

From the list of business income in 2019 between Jakarta and West Java with outside Jakarta and West Java has a percentage of $44.44 \%$ and $55.67 \%$, while in 2020, business income between Jakarta and West Java with outside Jakarta and West Java has a percentage of $50.71 \%$ and $49.29 \%$.

Table 5 List of Operating Income 2019 and 2020
\begin{tabular}{|l|l|l|l|l|l|l|}
\hline Geographic Segment & $\mathbf{2 0 1 9}$ & $\mathbf{2 0 2 0}$ & \multicolumn{1}{l|}{ Increase } \\
\cline { 2 - 7 } & Sum & Contribution & Sum & Contribution & Difference & \\
\hline Jakarta and Java West & $535.342,421$ & $44,33 \%$ & $513.286,636$ & $50,71 \%$ & $-22,055,785$ & \\
\hline Outside Jakarta and West Java & 610.942 .068 & $55,67 \%$ & $512,222,244$ & $49,29 \%$ & $-98,719,824$ & \\
\hline Total & 1.146 .284 .489 & $100,00 \%$ & 1.025 .550 .880 & $100,00 \%$ & $-120,733,609$ & \\
\hline
\end{tabular}

The main resources owned by the company are the strength of human resources, capital, and technology that affect the course of work. The company's human resources are adjusted technical reliability according to the background of the work to be done, always selecting employees who have qualified experience in the telecommunications industry and periodically conduct certified training. Sometimes companies also outsource experts for some jobs and take advantage of the massive network they have.

Technology is always updated in the construction of BTS and installation for work efficiency, it has been done by PT $\mathrm{XYZ}$ so that the company can cover all work activities throughout Indonesia except Eastern Indonesia in accordance with the specified schedule.

Key Activities or the main activities carried out by the company in order to realize the company's goals. The main activities carried out include the process of producing services. According to Ahyari (2002) production is a way or technique in increasing the usefulness of a good or service by involving existing production elements such as labor, production machinery, raw materials and the flow of funds (Capital).

The main activities carried out by the company in carrying out its business include the business analysis stage, development design stage, marketing stage and the last stage of construction before the unit is handed over to consumers. In the course of sometimes there are still processes that have not been running and not in accordance with business analysis such as immature market analysis and inaccurate risk management that result in problems projected such as problems in the legality of land and uncompetitive selling prices. So there must be a continuous market review of current property conditions, global benchmarking, trained and accurate risk management and corporate finance.

The next activity that continues to make the company run so far is to always upgrade experts / HR periodically because the use of technology used always changes over time, expanding the company's network by maintaining and making new connections with parties involved in this industry such as government elements, community leaders, and also consumer company officials. Then the company always tries to open closed regulations in every BTS development work area by means of political lobbying according to its designation. During this time the company to always prioritize teamwork in completing the work and distributing cash in accordance with its designation.

Organizations need partnerships for a variety of motives that generally aim for savings due to the non-achievement of economies of scale, reducing risk, acquiring resources or learning. Tower Provider and device providers here are also consumers and partners of the company in their operations because both parties have complementary contracts for BTS construction work to be completed. However, when viewed from supplier glasses, so far companies providing construction materials such as concrete, 
steel, and cable or development service providers as the main partners of companies for example in the field of Civil, Mechanical and Electrical Materials, and Panels. As for financial matters, Bank BRI is still the main partner of the company so far.

The cost structure is very dependent on managing key resources (key resources) of key activities owned by the organization (key activities) and partnerships built to facilitate business processes running (key partnership).

The main cost so far is operational costs because it needs a large cost for the mobilization and distribution of goods and human resources in a team. Of course, this is coupled with other expenses such as installation costs and the distribution of device commissions as well as consideration of regulatory costs that must be incurred.

\begin{tabular}{|c|c|c|c|c|}
\hline $\begin{array}{l}\text { Key } \\
\text { Patnership }\end{array}$ & Key Activities & $\begin{array}{l}\text { Value } \\
\text { propositions }\end{array}$ & Customer Relationship & $\begin{array}{l}\text { Customer } \\
\text { Segments }\end{array}$ \\
\hline \multirow[t]{3}{*}{$\begin{array}{ll}\text { 1. } & \text { Raw material } \\
& \text { supplier } \\
\text { 2. } & \text { Tower Provider } \\
\text { 3. } & \text { Bank }\end{array}$} & $\begin{array}{ll}\text { 1. } & \text { Upgrading TBSP } \\
\text { 2. } & \text { Expand Networking } \\
\text { 3. } & \text { Upgrading TBSP } \\
\text { 4. } & \text { Opening up regulations that } \\
& \text { hinder } \\
\text { 5. } & \begin{array}{l}\text { Distribution of cash } \\
\text { Precisely }\end{array}\end{array}$ & \multirow[t]{3}{*}{$\begin{array}{l}\text { 1. "All area" work } \\
\text { 2. Appropriate } \\
\text { specifications, } \\
\text { the latest } \\
\text { knology } \\
\text { 3rack Record } \\
\text { good }\end{array}$} & $\begin{array}{l}\text { 1. Timely completion of work } \\
\text { 2. Coordination Real-time }\end{array}$ & \multirow[t]{3}{*}{$\begin{array}{ll}\text { 1. } & \text { Tower } \\
\text { Provider } \\
\text { 2. } \\
\text { BTS } \\
\text { Device } \\
\text { Provider }\end{array}$} \\
\hline & \multirow{2}{*}{ 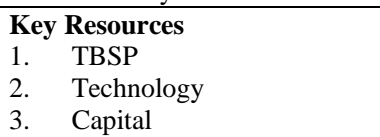 } & & Channels & \\
\hline & & & $\begin{array}{l}\text { 1. Bidding is open through } \\
\text { vendor auctions } \\
\text { 2. Networking company }\end{array}$ & \\
\hline \multicolumn{2}{|l|}{ Cost structure } & \multicolumn{3}{|c|}{ Revenue stream } \\
\hline \multicolumn{2}{|c|}{\begin{tabular}{ll}
\multicolumn{2}{l}{ Operating and regulatory expenses } \\
1. & Peland rizinan $(15 \%)$ \\
2. & Construction $(62.5 \%)$ \\
3. & HR development $(20 \%)$ \\
4. & Tax $(2.5 \%)$
\end{tabular}} & & \multicolumn{2}{|c|}{ Termyn payment (gradual payment) from the consumer } \\
\hline
\end{tabular}

Figure 2 Business Model Canvas PT XYZ

\section{Evaluation of Internal Factors}

At the stage of evaluation of internal factors, interviews and questionnaires are conducted to identify internal factors that affect the business development of PT XYZ. According to Rangkuti (2015), the preparation of the results of the identification of internal factors that affect the company is important to formulate an IFE (Internal Factor Evaluation) table containing these internal strategic factors within the framework of strength and weakness. IFE analysis is the result of internal factors consisting of strengths and weaknesses that PT XYZ has.

The results of weighting and rating on internal factors are based on the source / informant who filled out a questionnaire about PT XYZ. In Table 6 internal factors (strength) IFE can be seen that there are various ratings on the strength factor of PT $X Y Z$. Factors that have a rating with a value of 4 (outstanding) is the largest factor and is the most influential factor on the strength of PT XYZ, namely as follows:
1. Strong capital and experience has a score of 0.60 .

2. A good company image has a score of 0.60

3. Competitive human resources has a score of 0.45

4. Relationship strength with customers has a score of 0.45

Table 6 Weight Factors and Strength Rating of PT XYZ

\begin{tabular}{|l|l|l|l|l|}
\hline No. & Strength human & 0,15 & 3 & 0,45 \\
\cline { 3 - 5 } 1 & $\begin{array}{l}\text { Competitive aner } \\
\text { resources }\end{array}$ & Weight & Rating & Score \\
\hline 2 & $\begin{array}{l}\text { Strong capital and } \\
\text { experience }\end{array}$ & 0,15 & 4 & 0,60 \\
\hline 3 & $\begin{array}{l}\text { The power of relationships } \\
\text { with customers }\end{array}$ & 0,15 & 3 & 0,45 \\
\hline 4 & Qualified suppliers of goods & 0,12 & 3 & 0,36 \\
\hline 5 & Good corporate image & 0,15 & 4 & 0,60 \\
\hline & Total & $\mathbf{0 , 7 2}$ & & $\mathbf{2 , 4 6}$ \\
\hline
\end{tabular}

In Table 4. 4 internal factors (weaknesses) IFE can be seen that there are various ratings on the weakness factor of PT $\mathrm{XYZ}$. Factors that have a rating with a value of 1 are the highest weakness factors that affect PT XYZ, namely limited mobilization outside java island, upgrading technical 
problems and the size of employees who are not too large who both have a score of 0.04 . PT XYZ has the smallest disadvantage that does not have a new service offering and supplier relations outside Java are still few where both have a score of 0.08 . This means that PT XYZ immediately acted to improve the quality and quantity both in terms of labor, distribution of goods and deft to technical problems.

Table 7 Weight Factors and Disadvantage Rating of PT XYZ
\begin{tabular}{|l|l|l|l|l|}
\hline No. & Weakness & \multicolumn{2}{|c|}{ Disadvantages of PT XYZ } \\
\cline { 3 - 5 } & & Weight & Rating & Score \\
\hline 1 & Limitations of mobilization outside Java Island & 0,04 & 1 & 0,04 \\
\hline 2 & Upgrading technical issues & 0,04 & 1 & 0,04 \\
\hline 3 & The size of the company's permanent employees that are not too large & 0,04 & 1 & 0,04 \\
\hline 4 & We don't have a new service offer yet. & 0,08 & 1 & 0,08 \\
\hline 5 & Supplier relations outside Java are still few & 0,08 & 1 & 0,08 \\
\hline & Total & $\mathbf{1}$ & $\mathbf{0 , 2 8}$ \\
\hline
\end{tabular}

The internal condition of PT XYZ can be seen in Table 8 which is worth 2.74 is obtained from the sum of item weights on each of the strengths and weaknesses of the respondent's assessment multiplied by the rating of each strength factor and weakness factor given by the owner. The internal condition of PT XYZ is well stated because the average value of the company's strength factor is higher than the average value of the company's weakness.

In the strength factor with the largest score value, namely strong capital and experience and a good company image, each indicator has a score of 0.60. Followed by competitive human resources, the strength of relationships with customers who have a score of 0.45 . And, the smallest strength with a score of 0.36 , namely a qualified supplier of goods.

First, PT XYZ has strong capital and experience, the company has strong financial reserves in case its business operations do not meet revenue targets for profit. This makes the company sometimes still able to complete the work ordered by consumers (Tower Provider) although sometimes these consumers have not made payments so that cash flow is slightly hampered.

Table 8 Internal Factors (IFE) of PT XYZ
\begin{tabular}{|l|l|l|l|l|}
\hline No. & Factor & \multicolumn{3}{l|}{ IFE PT XYZ } \\
\cline { 2 - 5 } & & Weight & Rating & Score \\
\hline Strength & 0,15 & 3 & 0,45 \\
\hline 1 & Competitive human resources & 0,15 & 4 & 0,60 \\
\hline 2 & Strong capital and experience & 0,15 & 3 & 0,45 \\
\hline 3 & The power of relationships with customers & 0,12 & 3 & 0,36 \\
\hline 4 & Qualified suppliers of goods & 0,15 & 4 & 0,60 \\
\hline 5 & Good corporate image & & \multicolumn{2}{l|}{} \\
\hline Weakness & 0,04 & 1 & 0,04 \\
\hline 1 & Limitations of mobilization outside Java Island & 0,04 & 1 & 0,04 \\
\hline 2 & Upgrading technical issues & 0,04 & 1 & 0,04 \\
\hline 3 & Permanent employee size A company that is not too big. & 0,04 & 0,08 \\
\hline 4 & We don't have a new service offer yet. & 0,08 & 1 & 0,08 \\
\hline 5 & Supplier relations outside Java are still few & 0,08 & 1 & 0,08 \\
\hline & TOTAL & $\mathbf{1}$ & & $\mathbf{2 , 7 4}$ \\
\hline
\end{tabular}

Second, the good image of XYZ company is that consumers who are large companies do not want to mess around in choosing a contractor to get the job done. Here PT XYZ has a good track record in the eyes of consumers because so far the company always finishes work on time and is able to minimize the obstacles of bts development well. Consumers usually consider what the company's service offerings are, financial health, and the length of time the work will be completed.

The third Strength Factor is, competitive Human resources, PT XYZ always upgrading to all its human resources to keep up with the times in the use of technology carried out on daily operations. The company also strictly selects to recruit experts in doing a job. 
The fourth strength factor, PT XYZ has the strength of relationship with customers, in the B2B business model, the importance of the relationship between the two transacting parties is very important because it can affect the course of both parties' business in the future. PT XYZ has a strong network of connection relationships with decision holders in consumer companies, so that the decision holders have known that the company has been able to get the job done well.

The power factor of PT XYZ that has the least influence is a qualified supplier of goods, namely PT XYZ has a supplier who is never late in the provision of goods and does not have financial problems. Therefore, the distribution of these goods has never encountered any significant obstacles.

Therefore, in accordance with the research Mardatillah et al. (2013) it can be said that the evaluation of company performance is very important to improve performance in order to achieve company goals by evaluating the work process, targets, quality and achievement of employees, so that if the evaluation of employee performance is good it will have implications for good employee quality as well, it can also be said that good employee quality will be able to improve the quality of company service.

The highest weakness is that it has a low weight value and has a rating value of 1 , which is limited mobilization outside java island with a score of 0.04. Distribution outside Java Island which is still often experiencing difficulties because the company does not have meaningful power outside java island, still sometimes balanced with local power. According to Erni (2007) about the limited mobilization of a unit can be due to the absence of excellence of the company in the intended field, so that a strategy is needed to achieve maximum distribution and be able to compete with similar companies in the market. The next drawback is upgrading technical problems. The company has technical problems that still use old methods in running business operations, need to upgrade in order to perform work completion time efficiency.

\section{Evaluation of External Factors}

Maulana (2016) explained in his research that the external environment of a business is factors that have limits beyond the control of the business but the existence of these factors also influences the choice of direction and action of the business venture. The external environment is divided into three interrelated sub-categories, namely the remote environment, the industrial environment, and the operational environment. Distant environments are also called macro environments or general environments because they contain components whose influence is broad and included in the entire business process. The weighting and rating of external factors (EFE) of PT XYZ is based on the source / informant who fills out a questionnaire about PT XYZ. The average of the external factors (odds) of PT XYZ can be seen in Table 9.

Table 9 Indicators of Weight and Opportunity Rating of PT XYZ

\begin{tabular}{|l|l|l|l|l|}
\hline \multirow{2}{*}{ No. } & Chance & \multicolumn{2}{|c|}{ Pt XYZ Opportunities } \\
\cline { 3 - 5 } & & Weight & Rating & Score \\
\hline 1 & Device installation market and its maintenance (aftersales) & 0,14 & 3 & 0,42 \\
\hline 2 & Technology development that won't die & 0,14 & 4 & 0,56 \\
\hline 3 & There is a financial trust in the company. & 0,08 & 4 & 0,32 \\
\hline 4 & A very large population of people & 0,06 & 3 & 0,18 \\
\hline 5 & Changes in people's lifestyles & 0,06 & 4 & 0,24 \\
\hline & Total & $\mathbf{0 , 4 8}$ & & $\mathbf{1 , 7 2}$ \\
\hline
\end{tabular}

In Table 10 it can be seen that there are various ratings on the opportunity factor of PT XYZ. Factors that have a rating with a value of 4 (outstanding) is the most influential opportunity factor for PT XYZ. The factor that has the greatest value is indicated by a score of 0.56 , namely the 
development of technology that will not die.

Other opportunities factors are as follows:

1. There is a financial trust in the company.

2. Changes in people's lifestyles

3. Device installation market and its maintenance

4. A very large population of people

Table 10 Indicators of Weight and Threat Rating of PT XYZ

\begin{tabular}{|l|l|l|l|l|}
\hline No. & Threat & \multicolumn{3}{|l|}{ Threat of PT XYZ } \\
\cline { 3 - 5 } & & Weight & Rating & Score \\
\hline 1 & $\begin{array}{l}\text { Regulations of different } \\
\text { regions }\end{array}$ & 0,13 & 4 & 0,52 \\
\hline 2 & $\begin{array}{l}\text { Dwindling development } \\
\text { space }\end{array}$ & 0,13 & 4 & 0,52 \\
\hline 3 & $\begin{array}{l}\text { Current economic instability } \\
\text { Fluctuating regional } \\
\text { political conditions }\end{array}$ & 0,08 & 3 & 0,24 \\
\hline 5 & $\begin{array}{l}\text { Higher consumer bargaining } \\
\text { value }\end{array}$ & 0,06 & 4 & 0,48 \\
\hline & Total & $\mathbf{0 , 5 2}$ & & $\mathbf{2 , 0 0}$ \\
\hline
\end{tabular}

In Table 10 can be seen the score of the threat factor on PT XYZ. Factors that have the rating with the least impact on PT $\mathrm{XYZ}$ are the current economic instability and higher consumer bargaining value has a score of 0.24. The biggest threat factor for PT XYZ is the regulation of each different area and the dwindling development space has a score of 0.52 .

The total EFE value of PT XYZ is 3.72 obtained from the sum of item weights on each indicator of opportunity and threat factors. The external condition of PT XYZ is well stated because the average value of the company's opportunity factor is higher than the average value of the company's threat. The external factors (EFE) of PT $\mathrm{XYZ}$ can be seen in Table 11 .

Table 11 External Factors (EFE) of PT XYZ

\begin{tabular}{|l|l|l|l|l|}
\hline \multirow{2}{*}{ No. } & \multirow{2}{*}{ Chance } & \multicolumn{3}{|l|}{ EFE PT XYZ } \\
\cline { 3 - 5 } & & Weight & Rating & Score \\
\hline 1 & Device installation market and its aftersales & 0,14 & 3 & 0,42 \\
\hline 2 & Technology development that won't die & 0,14 & 4 & 0,56 \\
\hline 3 & There is a financial trust in the company. & 0,08 & 4 & 0,32 \\
\hline 4 & A very large population of people & 0,06 & 3 & 0,18 \\
\hline 5 & Changes in people's lifestyles & 0,06 & 4 & 0,24 \\
\hline & Threat & & & \\
\hline 1 & Regulations of different regions & 0,13 & 4 & 0,52 \\
\hline 2 & Dwindling development space & 0,13 & 4 & 0,52 \\
\hline 3 & Current economic instability & 0,08 & 3 & 0,24 \\
\hline 4 & Fluctuating regional political conditions & 0,12 & 4 & 0,48 \\
\hline 5 & Higher consumer bargaining value & 0,6 & 4 & 0,24 \\
\hline & TOTAL & 1 & & 3,72 \\
\hline
\end{tabular}

In the table shows that at the first highest opportunity factor, namely the development of technology that will not die, namely the development of technology that continues to progress, mobile phone users continue to increase every time so that the demand for signals from BTS increases, opportunities for the company to develop its business in the development of BTS and the development of BTS service features. Furthermore, there is a financial entity trust in the company, namely financial opportunities for the company because it can be a safety net for the company to continue to run its business operations if it turns out that there are obstacles in cash flow. And, changes in people's lifestyles, namely lifestyles are closely related to the development of the times and technology. The more the times and the more sophisticated the technology, the wider the application of lifestyle by humans in everyday life (Pawnshop, 2018). Lifestyle shifting that occurs today that considers as if the cell phone has become a primary need in everyday life than before which is secondary even tertiary for an individual. There is also, Prakoso and Syafiq (2020) stated that technology is growing due to rapid development along with changes in people's lifestyles in using the internet.

Another factor that has the next lowest value is the higher consumer bargaining value. Consumers who are large companies and can choose contractors to get their work done make the company must still have a good image and good offers in order to remain the consumer's top choice. Rofik (2017) states that consumer 
bargaining power has an influence on the condition of a business.

Analysis of factors to increase competitiveness through the application of human resource performance management in the company is one of the important aspects in the formulation of the company's strategy in order to achieve maximum competitiveness. Analysis of supporting factors aims to categorize factors using ranking scores so that they can be known the factors with the highest values and lowest values. Analysis of kinera supporting factors in this study was conducted using the Analytical Hierarchy Process (AHP) method. The Analytic Hierarchy Process (AHP) method is a comprehensive methodology, which provides the ability to combine quantitative and qualitative factors in individual and group decision-making (Saaty 2012).

Basically AHP is a method of solving a complex and unstructured problem intoits components, arranging those components in a hierarchy, including numerical values in lieu of human perception in making relative comparisons, and finally producing a synthesis that establishes the order and priority values of those components. AHP is displayed in the form of a hierarchical model consisting of objectives, criteria, perhaps several subcriteria levels and alternatives to each decision (Nurmianto and Siswanto 2006).

\section{Alternative Analysis of Business Strategies}

The results of internal factor analysis using the IFE matrix obtained a score of 2.74 and the results of external analysis using the EFE matrix obtained a score of 3.72. The total score indicates that PT XYZ's strategy is effectively able to profit from existing opportunities and minimize the negative influence of external threats because it has a score above average.

Judging from the IE matrix, the company's position is in quadrant II with the position in the medium category depicted in Figure 4.3. This indicates that the most appropriate grand strategy carried out by PT $\mathrm{XYZ}$ is growth and build strategy, and the strategies that can be developed are market penetration, and product development. $\mathrm{Pt}$ $X Y Z$ 's internal and external strategy factor matrix can be seen in Figure 4. 2 .

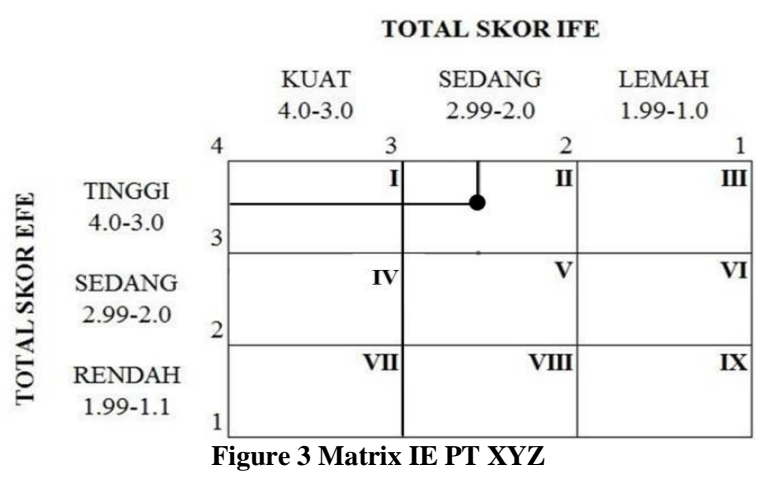

Figure 3 indicates that the condition of PT XYZ is in cell II which is called the strategy of growing and building. In this position, the company can implement growth strategies through vertical integration. This is a key strategy for companies that have a strong market competitive position in high attractive industries. In order to increase its business strength or competitiveness, PT XYZ must improve its marketing strategy. One of them is that it can be done promotion and market penetration by spreading its wings outside java island by increasing the quality and quantity of resources owned by PT XYZ. This promotion can be done by doing advertising, selling personnel, sales promotion, direct marketing, and public relations (Purwanti 2012).

\section{Alternative Formulation Strategies}

A study shows that a company's performance can be determined by a combination of internal and external factors. Both factors should be considered in a SWOT analysis. Based on the results of the IFE matrix, PT XYZ has a strong internal position above average with a total score of 2.74. While from the EFE matrix, PT XYZ is able to benefit from existing opportunities and minimize the negative influence of external threats because it has a score of 
3.72 so that PT XYZ has a considerable chance compared to the threat.

Based on the SWOT matrix, there are various strategies that can be used by PT XYZ. But seeing PT XYZ who has a strong internal position and is able to take advantage of opportunities, then PT XYZ should conduct a SO (StrengthOpportunities) strategy by using the power to take advantage of existing opportunities through expanding the market by increasing market penetration and promotion, as well as improving the quality of service.

\section{Priority Strategy Analysis}

The priority assessment of the QSPM method strategy by multiplying the weights on the IFE and EFE matrices, multiplying them by the attractive score to generate a Total Attractive Score (TAS). The overall number of TAS of each such strategy determines the priority of the strategy, Determination of Attractive Score (AS) in QSPM and Processing of Total Attractive Score (TAS) QSPM can be seen in. All alternative strategies that are lysed using QSPM on PT XYZ are as follows:

1. Training and development;

2. Repositioning expands the target segment by differentiation using a market penetration system;

3. PT XYZ must find prospective employees with a subcon system, with a record of having to pass training;

4. Increase marketing effectiveness;

5. Increase company awareness in every operational area

6. Monitoring of regulations, both local, political and monitoring about consumers, to know what to improve;

7. Create and improve the quality of new service products such as after-sales and services that are predictive of the future

Based on the results of the QSPM assessment, it is obtained the order of TAS value (Total Attractiveness Score) the highest to the lowest. Then the first priority strategy is to conduct training and development by PT XYZ is expected to be active and consistent with the highest TAS score of 4.8. Repositioning strategy by expanding segment targets to increase the number of comments in line with porter's research (2018).

Judging from the IE matrix, the company's position is in quadrant II with positions in the medium high category. This means that PT XYZ is in a grow and build position, the recommended strategies are market penetration and product development. Strategies can be done by still utilizing the strengths and opportunities they have and overcoming weaknesses and anticipating threats both from the internal environment and the external environment of the company. In the SWOT matrix, there have been nine alternative strategies that can be formulated with QSPM and obtained priority strategies that can be implemented by the company. Seven priority strategies can be grouped on grow and build strategies in the IE matrix.

\section{Alternative Formulation Strategies}

The stage is done by identifying the nine building blocks of the business model that is running at $\mathrm{PT} X Y Z$ and then describing it on the Business Model Canvas. Companies that want to improve their business continuity must change their business model that can be implemented inkramental (little by little on a regular basis) (Boons and Freund 2013).

\section{Customer Segments}

PT XYZ segments extensively and evenly using classifications and priorities, as well as if the consumer is loyal must be maintained. For example, Nokia Solutions and Networks Indonesia as a provider of device installation services on a telecommunication tower with business to business principles because it already has a cooperation contract between the two parties implements a win win solution so that a trust is maintained.

\section{Value Propositions}

The Company conducts training and development with a subcon workforce, both 
from technical and regulatory work. It also emphasizes the importance of discipline and timely.

\section{Channels}

Business to business activities that acquire goods and services used to produce other products or services sold, leased or supplied to others (Kotler and Keller 2016). PT XYZ delivers the company's value offering by combining direct and indirect methods. Direct channels used by the company include through open bidding when tower providers conduct vendor auctions and also competitive contractpaying offers that are directly submitted to consumer companies.

\section{Customer Relationship}

PT XYZ with its consumers who are large companies and certainly have stronger bargaining value. So the relationship built to keep them afloat is to maintain the quality of tower and device specifications as promised at the beginning, complete the work on time according to the schedule that has been set, and maintain coordination quickly and real-time. As long as the track record of work is maintained properly then consumers still choose PT XYZ to complete the work.

\section{Revenue Stream}

The company has revenue streams through tower construction services and installation of BTS devices. Payments made by consumers are by way of Termyn in accordance with the progress that has been done by the company where the payment is made through bank channels that have cooperated, then healthy bank traffic is the key to the company in carrying out its business operations so far. Another revenue stream is offering BTS maintenance services that have been done by the company.

\section{Key Resources}

The main resources owned by the company are the strength of human resources, capital, and technology that affect the course of work. The company's human resources are adjusted technical reliability according to the background of the work to be done, always selecting employees who have qualified experience in the telecommunications industry and periodically conduct certified training. Sometimes companies also outsource experts for some jobs and take advantage of the massive network they have.

\section{Key Activities}

The main activity that continues to make the company run so far is to always upgrade experts / HR periodically because the use of technology used always changes over time, expanding the company's network by maintaining and making new connections with parties involved in this industry such as government elements, public figures, and also consumer company officials.

\section{Key Partnership}

Organizations need these partnerships for a variety of motives that generally aim for savings due to the nonachievement of economies of scale, reducing risk, acquiring resources or learning. Tower Provider and device providers here are also consumers and partners of the company in their operations because both parties have complementary contracts for BTS construction work to be completed. $\mathrm{H}$

\section{Cost Structure}

The cost structure is very dependent on managing key resources (key resources) of key activities owned by the organization (keyactivities) and partnerships built to facilitate business processes running (keypatnership). The main cost so far is operational costs because it needs a large cost for the mobilization and distribution of goods and human resources in a team. Of course, this is coupled with other expenses such as installation costs and the distribution of device commissions as well as 
consideration of regulatory costs that must be incurred.

\section{CONCLUSION}

Based on the results of the study, BMC told PT XYZ, that the business model of the company can still sustain its business operations but there are some slight shortcomings that need to be improved to maximize the elements that can increase profits from the company. Therefore, there is a change in BMC from initially less content to increasing, especially those in the cost structures and revenue stream elements.

The results of the analysis of strategy formulation and SWOT analysis resulted in seven alternative strategies, namely increasing marketing effectiveness, reposition to expand segment targets with differentiation using market penetration systems, monitoring on regulation, both regional, political and monitoring about consumers, in order to know what to improve, PT XYZ must find prospective employees with subcon systems, with a record of having to pass training, regulation and development, increase company awareness in every operational area, and create and improve the quality of new service products such as after-sales services and services that are predictive of the future.

In the QSPM analysis, the main priority strategy is training and development HR with a TAS score of 4.8. This aims to overcome the main problem of PT XYZ, which is to increase the revenue needed competent resources by improving quality and quantity. Thus, there is an improvement in the business model canvas (BMC) that changes some elements such as cost structure and revenue stream elements.

\section{Acknowledgement: None}

Conflict of Interest: None

Source of Funding: None

\section{REFERENCES}

1. [APJII] Indonesian Internet Service Providers Association. 2019. Infographic penetration \& Behavior of Indonesian Internet Users: Survey 2017-2019. Jakarta: APJII.

2. [APJII] Indonesian Internet Service Providers Association. 2020. The Internet Is The New Breath of Life in the Midst of a Pandemic. [accessed 2021 Apr 29]. https://nasional.kompas.com/read/2021/04/0 4/09020061/internet-sudah- so-breath-newlife-in-the-middle of-pandemic.

3. Arjanggi, S., Wahyuni, E., \& Soewardojo. 2012. Comparative Study of Bts Tower Structure Type SST Foot 4, SST Foot 3 and Monopole with The Most Efficient Height of 40m. POMITS Technical Journal, 1(1), 1-5.

4. Central Bureau of Statistics. 2020. Covid-19 Press All Business Sectors. [accessed 2021 Mar 25]. https://covid19.bps.go.id/home/infografis.

5. Central Bureau of Statistics. 2021. Indonesia's economy 2020 decreased by 2.07 percent. [accessed $2021 \quad$ Mar 25].

https://www.bps.go.id/pressrelease/2021/02/ 05/1811/ekonomi-indonesia- 2020-downby-2-07-percent--c-to-c-.html.

6. Central Bureau of Statistics. 2021. Indonesia's Economic Growth In The Fourth Quarter of 2020 Continues improvement. [accessed 2021 Mar 25]. https://www.bi.go.id/id/publication/spacemedia/news-release/Pages/sp_233321.aspx.

7. Business. 2020. Observer: BTS Is Not Much Needed in the Big City. [accessed date 2021 Apr

https://teknologi.bisnis.com/read/20200213/ 101/1200838/pengamat-bts- not- muchneeded-in-big-city.

8. Buttle, Francis. 2007. Customer Relationship Management. Jakarta: Bayumedia Publishing.

9. David, Fred R dan Forest R. David. 2017. Strategic Management concepts and cases A Competitive Advantage Approach. Sixtennth Edition. England: Pearson Education Limited.

10. Erni A. 2007. Milk Marketing Mix. [Thesis]. Jambi University (ID): Jambi Fauzi, A. 2014. Planning for Base Transceiver Station (BTS) Needs 
11. Optimization of Tower Placement With Telecommunication Requirements Planning Base Transceiver Station (BTS) Placement and Optimization of Shared Telecommunications. Journal of Communication And Information Research and Development,4(3), 151-159.

12. Grant, J. 2007. The Green Marketing Manifesto. John Wiley \& Sons, Ltd., West. Sussex, England. Journal of Business Ethics, Vol.29

13. Haq, Dliya Ul. 2019. Analysis of Formulation of Virtual Gas Pipeline (CNG \& LNG) Business Development Strategy [thesis]. Bogor: Bogor Agricultural Institute.

14. Herawati, Novitha., Triana Lindriati and Ida Bagus Suryaningrat. 2019. Application of Canvas Business Model in Determining Edamame Goreng Soybean Business Management Plan. Journal of Agrotechnology 13(1)

15. Hilgret MA, Jeanne HM. 2003. Household Financial Management: The Connection between Knowledge and Behavior'. Federal Reserve Bulletin.

16. Hooper, D. Coughlan. 2008. Structural Equation Modelling: Guidelines for Determining Model Fit Electronic. Journal of Business Research. 2(1):45-55.

17. Ibrahim, Syufriadi. 2019. Analysis of Footwear Business Development Strategy at CV Hikmah Shoes[thesis]. Bogor: Bogor Agricultural Institute.

18. Indotelko. 2019. 4500 XL towers will belong to whom? . [accessed 2021 Apr 21]. https://www.indotelko.com/read/157421536 4/menara-xl-siapa.

19. Jauch, L.R. and Glueck W.R. 2013. Strategic Management and Corporate Policy: Edition 4. Jakarta: Erlangga

20. Jayadi, Nor., and Rahmawan Prasetya. 2017. Public Perception of BTS Tower Camouflage Design in Urban Environment Case Study: Yogyakarta City. Conference Paper: International Symposium of Art, Craft, and Design in Southeast Asia Vol 1

21. Kastoyo, Rendy Tanuwijaya. 2013. Agrotourism Business Development Strategy Bukit Baros Cempaka District Baros Sukabumi Regency [thesis]. Bogor: Bogor Agricultural Institute.

22. Katadata. 2020. Smartphone Users are expected to reach $89 \%$ of the population by 2025. [accessed 2021 Mar 25].
23. https://databoks.katadata.co.id/datapublish/2 020/09/15/pengguna-smartphone-estimatedreaches-89-population by-2025.

24. [Kominfo] Ministry of Communication and Informatics. 2020. Kominfo Bangun

25. 4,200 BTS For The Internet In 2021. [accessed 2021 Mar 25]. https://kominfo.go.id/content/detail/31756/k ominfo-bangun-4200-bts- demi-villageelectricity-internet-in2021/0/sorotan_media.

26. Kluyver, Cornelis and John A. Pearce II. 2006. Strategy: A View From The Top. Australia: Pearson

27. Luthfi M and Haspita F. 2018. Service quality analyst to strategic business ventures (Case study: PT XYZ mining and mineral focus). Journal of Business Administration. 1(1): 49-64.

28. Luthan, M. Zulkyfli. 2019. Analysis of The Development of The Canvas Business Model of Holtikultura Company PT. XYZ. Journal of Agribusiness Forum 9(2)

29. Honeyra, Jeff. 2009. International Corporate Finance 9th Edition. South-Western Oktapriyandi, Digdoyo. 2017. Business Model Development Analysis on

30. Maulana AK, Mila, and Rina O. 2016. Business Strategy of PT. Pariwara Advertising in DKI Jakarta Outdoor Media Industry. Journal of Business Applications and Management. 3(1): 20-32.

31. The Animation Industry Uses a CostLimited Canvas Business Model. Journal of Teknoin 23(3): 195-210

32. Osterwalder, A and Pigneur, Y. 2012. Business Model Generation: A Handbook for Visionaries, Game Changers and Challangers. New Jersey: John Wiley \& Sons, Inc.

33. Pasek, I.K., Syarief R and Sahara. 2017. The Business Model Analysis of WIKA Lab Using Business Canvas Approach. European Journal of Business and Management 9(12)

34. Pearce II, John A. and Richard B. Robinson, Jr. $\quad 1997 . \quad$ StrategicManagement: Formulation, Implementation, and Control: FirstEdition. Jakarta: Binarupa Aksara

35. Pearce II, John A. and Robinson, Richard B. 2013. Strategic Management: Formulation, Implementation, andControl. Jakarta: Salemba Four.

36. Pawnshop. 2018-2019. Financial \& Annual and strategic statements. 
37. Porter, Michael E. 2018. Competitive Advantage: Creating and Maintaining Superior Performance 2ndMold. Jakarta (ID): PT. Gelora Aksara Pratama.

38. Prakoso D and Syafiq M. 2020. The relationship between the perception of social media marketing and the decisions of technology service users. Character: Journal of Psychological Research. 7(3): 74-83.

39. Purbo, Onno. W. and Aang Arif Wahyudi. 2001. Getting to know E-commerce. Jakarta: PT Elex Media Komputindo

40. Purwanti E. 2012. Influence of entrepreneurial characteristics, business capital, marketing strategies on the development of MSMEs in Dayaan Village and Kalilondo Salatiga. Among Makarti. 5(9): 13-28.

41. Puspitasari, N.B. 2012. Hyacinth craft business development strategy as the flagship product of Semarang Regency using value chain analysis. Journal of Industrial Engineering 7(2): 113-122.

42. Summary, Freddy. 2000. SWOT Analysis of Business Case Dissecting Techniques. Jakarta: Gramedia Pustaka

43. Summary, Freddy. 2015. Personal SWOT Analysis. Jakarta: PT Gramedia Pustaka Rofik A. 2017. The marketing strategy of shoe washing services in Surabaya (case study of fareclean shoes washing in Surabaya). Journal of Performance Management. 3(2): 109-124.

44. Sarosa, Samiaji. 2012. Qualitative Research: The Basics. Jakarta: Permata Puri Media..

45. Sarwono, Jonathan. 2006. Quantitative and Qualitative Research Methods. Yogyakarta: Graha Ilmu

46. Setini, Made. 2018. Designing a Business Model Based on Comparative Two Fitness
Centers To Increase Customer Numbers. Journal of Business Management 15(2)

47. Siagian, Sondang P. 2012. Human Resource Management. Jakarta: Bumi Aksara.

48. Sugiyono. 2013. Educational Research Methods Quantitative, Qualitative, and R\&D Approaches. Bandung: Alfabeta.

49. Sunarto. 2019. Palm Oil Crop Insurance Development Strategy With Canvas Business Model Approach (Case Study: PT. Insurance Tri Pakarta) [thesis]. Bogor: Bogor Agricultural Institute.

50. Thompson, A. A., Stickland, A. J., \& Gamble, J. 2010. Crafting and Executing Strategy, 17th/E. New York: McGraw-Hill Irwin

51. Umar, Hussein. 2010. Marketing and Business Research. Jakarta: Gramedia Pustaka Utama

52. Usman, Abdul Halim. (2015). Sharia Strategic Management: Theory, Concepts andApplications. Jakarta: Zikrul Hakim

53. Wahyudi, Adi Novi. 2017. Business Development Strategy Using Canvas Model at PT Nusantara Terminal Services in Makassar [thesis]. Makassar: Hasanuddin University.

54. Wheelen, T.L. 2012. Strategic Management and Business Policy: Toward Global Sustainability (13th Edition). New York: Pearson.

How to cite this article: Koswara BM, Syarief $\mathrm{R}$, Harianto. Business development of base transceiver station (BTS) infrastructure contractor PT. XYZ. International Journal of Research and Review. 2021; 8(9): 453-467. DOI: https://doi.org/10.52403/ijrr.20210958 